\title{
ВПЛИВ ТЕХНОЛОГІЇ ВИРОБНИЦТВА МОЛОКА НА ЙОГО ЯКІСТЬ ТА БЕЗПЕЧНІСТЬ
}

\author{
Герун Інеса Володимирівна \\ аспірант \\ Сумський національний аграрний університет (м. Суми, Україна) \\ ORCID: 0000-0002-1674-3410 \\ gerun.inesa@gmail.com
}

Скляр Олександр Іванович доктор ветеринарних наук, професор Сумський національний аграрний університет (м. Суми, Україна) ORCID: 0000-0002-0111-1277 sklyar1956@gmail.com

Мусієнко Олексій Володимирович кандидат ветеринарних наук, доцент Сумський національний аграрний університет (м. Суми, Україна) ORCID: 0000-0002-4873-7023 aleksey_musya@ukr.net

В статі наведені дані санітарно-гігієнічного стану ферми при виробництві молока за традиційних та за новітньої технології. В даній роботі були проведені дослідження мікроклімату у приміщеннях для корів та його вплив на якість та безпечність молока. Нашими дослідженнями встановлено що якість та безпечність молока напряму залежить від технології його виробництва. За використання новітньої технології виробництва молока кількість соматичних клітин

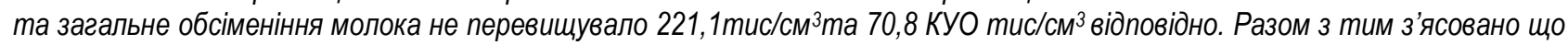
за використання новітньої технології виробництва молока в зимовий період часу температура в приміщення може опускатися до - $10^{\circ} \mathrm{C}$, але це не приводить до збільшеності захворювання на мастит та органи дихання. Захворювання корів на мастит не перевищує 6,4 відсотка що є одним із кращих показників.

Ключові слова: мікроклімат, молоко, сірководень, аміак, відносна вологість, загальне бактеріальне обсіменіння, швидкість повітря, вуглекислий газ, корови, мастит.

DOI: https://doi.org/10.32845/bsnau.vet.2020.4.3

Вступ. Забезпечення населення продуктами харчування $€$ глобальною соціально-економічною проблемою, яку необхідно вирішувати об'єднавши зусилля на всіх рівнях. Харчування було і буде актуальним та найсуттєвішим чинником, який здійснює постійний вплив на життя та здоров'я людини Hulich, M.P. (2011), Smolar, V.I. (2013), Zamoyski K. (2014). За сучасних умов виробництва молока виникає необхідна потреба щодо вивчення комплексу профілактичних заходів. Які б дозволили повністю використовувати генетичний потенціал тварин і разом з тим зберегти здоров'я та отримати якісну і безпечну продукцію від них. На тепер з'являється велика кількість технологічних новин, які направлена на отримання найбільшої продуктивності 3 найменшими затратами. За використання промислових технологій часто не враховують природні потреби тварин, які науково обгрунтовані відповідають певній фізіологічній групі. Досить часто виробничники змінюють проекти на свій розсуд та залежно від регіону. На сьогодні на ринку послуг пропонуються різні технології виробництва молока незважаючи на природно-кліматичні умови та добробут тварин. Останнім часом стали більше впроваджувати автоматизовані та роботизовані системи доїння (Dorofeev, O.V. and Buncev, V.E. (2015), Kernasyuk, Y. (2015), Kostenko, V. (2013), Kostenko, V. (2015), Kyryliuk, I. (2016). Отже природно виникає питання які ж найкращі технології 3 погляду на збереження здоров'я тварин, продуктивності, якості та безпечності продукції. Основними алгоритмами при виборі технології виробництва молока $€$ добробут тварин

який базується на умовах годівлі, напування та санітарногігієнічних нормах. Порушення цих постулатів неодмінно приведе до захворювання тварин, втрати продуктивності і як наслідок погіршення якості та безпечності молока.

Сучасні вимоги до молока сировини. Виробництво, якість та безпечність молока регламентуються Законом України «Про молоко та молочні продукти», за редакцією від 05.04.2015. та наказом Міністерства аграрної політики №118 «Про затвердження Вимог до безпечності та якості молока і молочних продуктів». Світова організація торгівлі (СОТ) встановлює нові вимоги до молока як сировини яка постачається на молокопереробні підприємства для виробництв молочної продукції. В зв'язку з цим у 2018 р. було розроблено та введено в дію новий національний стандарт ДСТУ 2662:2018 «Молоко-сировина коров'яче. Технічні умови», який містить характеристики та технічні умови для здійснення закупівлі та приймання молока коров'ячого з мето його подальшого введення в обіг. Норми мікробіологічних показників були визначені ще в 1997 року і суттєво відрізнялися від таких у ЄС. Якщо раніше за стандартом 1997 молоко другого сорту приймалося на переробні підприємства то на тепер таке молоко вважається непридатним для виробництва молочних продуктів. Стандарт ДСТУ 2662:2018 направлений на підвищення вимог до якості та безпечності молока. Відповідно до чинних вимог виробники молока повинні впровадити належну виробничу практику. Молоко-сировина повинно відповідати ДСТУ 3662:2018 «Молоко-сировина коров'яче. Технічні умови». Кількість мезофільних аеробних 
і факультативно- анаеробних мікроорганізмів (КМАФАнМ за температури $\left.30{ }^{\circ} \mathrm{C}\right)$, тис. КУО/М³ ${ }^{3}$ повинно бути не більше для екстра гатунку $\leq 100$ для вищого $\leq 300$ для першого $\leq 500$, вміст соматичних клітин тис./ $\mathrm{cm}^{3}$ для ґатунку екстра та вищий $\leq 400$ для першого $\leq 500$.

Аналіз останніх досліджень і публікацій. На теперішній час виробництво найбільшої кількості продукції не зважаючи на якість нікому непотрібна. Отже наряду з кількістю продукції постала якість яку можна отримати лише від здорових тварин за умови відповідності санітарно-гігієнічних вимог при виробництві. Одним із основних санітарногігієнічних вимог у будівництві тваринницьких приміщень $€$ мікроклімат. До мікроклімату приміщення відносять освітлення, вентиляцію, загазованість, мікробну забрудненість які дозволяють тварині відчувати себе в зручному середовищі. На здоров'я та поведінку тварин і як наслідок на продуктивність впливають як зовнішні так і внутрішні чинники. Згідно закону про добробут тварин власники повинні надавати їм належний добробут та задовільні умови існування. Немаловажною причиною порушення мікроклімату у приміщенні $є$ скупченість тварин. Яка призводить до збільшення концентрації газів, вологості та бактеріального забруднення. Погіршення мікроклімату призводить до захворювання тварин та впливає на якість продукції (Andrievskyi, V. et al., 2013), (Arulraj, P et al.,2015), (Busato, A et al., 2000). Мікроорганізми які знаходяться у повітрі можуть потрапляти на шкіру та вим'я корів а звідти у молоко таким чином збільшуючи його бактеріальне обсіменіння. Крім того, підвищена вологість разом зі зниженням температури та протяги можуть привести до захворювання на мастит (Andrievskyi, V.et al., 2013), ( Shkromada, O. et al., 2019). Молоко відповідно до даних санітарно-епідеміологічної служби відноситься до продуктів першої категорії, які викликають харчові токсикоінфекції. В зв'язку з цим галузь тваринництва впроваджує міжнародні вимоги щодо якості та безпечності виробленої продукції. Саме для цього впроваджую принципи міжнародної системи НАССР. Основними принципами якої $€$ контроль якості та безпечності не на кінцевому результаті а протягом всього ланцюга виробництва (Kyryliuk, І., 2016), (Zamoyski, K. 2015). На сьогодні на теренах України значний відсоток молока виробляється за інтенсивною технологією але все ще більша частка дійних корів утримується хоча і в переоснащених але все ж таки приміщеннях які повністю не відповідають сучасним вимогам. Що не дозволяє отримати від них максимальну продуктивність безпечної та якісно продукції. Одним із чинників, який впливає на добробут тварин, є система утримання. В Україні діють нормативними актами щодо утримання дійних корів - ВНТП АПК-01.05 (скотарські підприємства). Сучасні умови утримання тварин в тому числі і корів вимагають використовувати безприв'язний метод. Але ще досить часто використовується прив'язне утримання. За безприв'язного утримання доїння тварин проходить у доїльних залах, санітарний стани яких дозволяє отримати молока найвищого гатунку. За прив'язного утримання навіть за найбільш сприятливих умов значна частина молока все-одно отримується нижчим класом. Хоча здорові корови виробляють молоко і в тих і других умовах умовно стерильним. Отже на якість та безпечність молока впливають умови утримання тварин та безпосередньо умови його отримання. Значна частина господарств за прив'язного способу утримання у теплий період року вико- ристовують літні табори. Тварини знаходяться на відкритому повітрі що дозволяє змінити мікроклімат, в достатній кількості отримати ультрасріолетове опромінення, оздоровитися. За приязного утримання для доїння використовуються доїльні установки АДУ -1. В переобладнаних приміщеннях використовується доїльна установка «Брацлав» Українського виробництва. Господарства які використовують новітню технологію для доїння використовується доїльна установка «ДеЛаваль» закордонного виробництва (Швеція).

Метою нашої роботи було вивчити санітарногігієнічні показнику виробництві молка молока отриманого за різних способів утримання та доїння корів.

Матеріали та методи дослідження. Одним із важливих фракторів у виробництві молока $є$ мікроклімат приміщень, який впливає на здоров'я та продуктивність тварин. Значна частина дослідників вважає, що для ефективного ведення молочної галузі потрібно дотримуватись вимог щодо технологічного процесу. Одним 3 найважливіших фракторів який впливає на організм тварин є зовнішнього середовища яке включає себе годівлю та мікроклімат. Від цього залежить як здоров'я так і продуктивність та якість продукції. В зв'язку з цим ми вирішили провести дослідження мікроклімату за різних технологій виробництва молока. Дослідження проводили у ТОВ АФ «За Мир» Сумського району за прив'язного способу утримання корів де використовується доїльна установка АДУ-1. Разом з тим дослідження проводили у ТОВ АФ «Лан» Сумського району Сумської області де використовуються заново збудовані приміщення для виробництва молока за новітньою технологією, також $є$ переобладнані приміщення і в тих і других корівниках використовується доїльна установка «Брацлав» українського виробництва. За прив'язного способу утримання в теплий період року тварини знаходяться в літньому таборі, та в холодний - у приміщенні. У переобладнаних приміщеннях корови утримуються безприв'язно і мають вільний вихід у дворики які розташовані біля приміщення. Найпершим показником мікроклімату є температурний режим за якого тварина себе почуває комфортно. Дослідження температури у приміщенні проводили максимальним ртутним термометром. Та мінімальним спиртовим. Термометри розташовувалися горизонтально на відстані 1,5 метра від підлоги та вікон , а також по діагоналі приміщення. Дослідження концентрації $\mathrm{CO}_{2}$ проводили за методом Суботіна-Нагорського. Слідуючим показником санітарно-гігієнічного стану приміщення $€$ аміак $\left(\mathrm{NH}_{3}\right)$. Аміак у приміщенні де утримуються тварини виділяється, в основному, із сечі за рахунок розпаду уреазотивних речовин. При тривалому впливі на організм навіть незначних концентрацій $(0,15 \%)$ аміаку погіршується загальний стан корів. Отже, концентрацію аміаку необхідно регулярно досліджувати та впливати на цей процес. Вміст аміаку досліджували за допомогою експрес-методу з 0,001 нормальним розчином сірчаної кислоти та індикатором Тоширо. Ще одним із показників умов утримання тварин $€$ сірководень $\left(\mathrm{H}_{2} \mathrm{~S}\right)$ який також може накопичуватись у приміщенні. Сірководень накопичується у корівниках із сірковмісних речовин органічного характеру. Разом з тим він може надходити із каналізаційної системи. Концентрацію сірководню визначали за допомогою газоаналізатора УГ - 2, мг/м3. Під час своєї роботи ми також визначали відносну вологість повітря у приміщенні. Як відомо з літературних джерел 
вологість повітря у приміщенні завжди вища ніж в атмосфрері. Відносна вологості тваринницького приміщення не повинна перевищувати $70 \%$. Але у деякі періоди у приміщенні відносна вологість може значно збільшуватися, що негативно відображається на здоров"ї тварин і може привести до захворювання. Для визначення відносної вологості повітря ми використовували статичний психрометр Августа. Визначаючи санітарно-гігієнічні параметри утримання корів ми також провели дослідження швидкості руху повітря у корівнику та дослідили бактеріальну забрудненість приміщення. Для визначення швидкості руху повітря у приміщенні використовували крильчатий анемометр АСО - 3. Дослідження загального бактеріального забруднення проводили за допомогою приладу Ю.А. Кротова по загально прийнятій методиці. Дослідження кількості соматичних клітин визначали мікроскопічним методом Прескотта-Бріда. Загальне обсіменіння молока досліджували за ДСТУ ISO 4833:2006.

Результати досліджень. Опрацьовуючи літературу ми виявили що та чи інша технологія виробництва молока свої переваги та свої недолік. До недавнього часу основною технологією виробництва молока була прив'язна система утримання корів. Перевагою цієї системи порівняно з безприв'язним $€$ те що визначається певна група корів за нею закріплюється оператор машинного доїння. Який детально знає індивідуальні підходи до кожної тварини. Це дозволяло отримувати вищу продуктивність. Така система утримання дозволяє виявляти своєчасно фрізіологічний стан кожної тварини. Разом з тим не достатком прив'язного утримання $є$ гіподинамія. Що в свою чергу приводить до захворювання кінцівок та інших систем та органів. Разом з тим тварини не отримують ультрафріолетове опромінювання, що також негативно відображається на організмі тварин. До недоліків також необхідно віднести збільшення ручної праці так як деякі процеси не можна механізувати. За прив'язного утримання на кожну тварини необхідно планувати більшу площу, також тварин необхідно періодично випускати на прогулянку що займає значну кількість часу. На теперішній час все більше господарств переходять на безприв'язну систему утримання корів. За такого способу протягом усього життя тварини знаходяться у приміщенні. Безприв'язний спосіб дозволяє зменшити витрати праці на одиницю об'єму виробленого молока. Разом з тим у даній системі важлива правильна організація праці. За безприв'язного утримання корів необхідно як можна більше механізувати роботу що дозволить зменшити собівартість молока. Разом з тим така технологія виробництва молока потребує відповідного обладнання як для транспортування так і первинної обробки. Корови розміщуються у секціях. Переваги цієї технології втім що до мінімуму зводиться ручна робота. Ефективне використання площі. Доїння тварин проводиться у доїльних залах де можна витримати санітарно-гігієнічні вимоги при доїнні. Недоліком є те що немає індивідуального підходу до корови. За такої технології виробництва молока суттєво зменшується продуктивний вік тварин. Разом з тим недоліком даної технології $€$ те що у секціях тварини повинні бути одного віку. Неможна змішувати корів із інших секцій так як це приводить до конфліктів між тваринами. Отже на тепер існує ціла низка наукових і практичних підходів до технологій виробництва молока кожна 3 яких має як негативні так i позитивні відгуки.

Таблиця 1

Мікроклімат приміщення та санітарно-гігієнічні показники молока за прив'язного способу утриманні корів, $(\mathrm{M} \pm \mathrm{m}, \mathrm{n}-5)$

\begin{tabular}{|c|c|c|c|c|c|}
\hline \multirow{2}{*}{ Показники } & \multirow{2}{*}{ Норма } & \multicolumn{4}{|c|}{ Пора року } \\
\hline & & Літо & Осінь & Зима & Весна \\
\hline Температура повітря у приміщенні, ${ }^{\circ} \mathrm{C}$ & $8-12$ & - & $\begin{array}{c}+11,1 \\
\pm 2,1\end{array}$ & $\begin{array}{c}+5,2 \\
\pm 1,1^{*}\end{array}$ & $\begin{array}{c}+12,6 \\
\pm 1,7\end{array}$ \\
\hline Відносна вологість, \% & 70 & - & $\begin{array}{c}75,2 \\
\pm 0,53\end{array}$ & $\begin{array}{c}82,7 \\
\pm 0,64^{*}\end{array}$ & $\begin{array}{r}62,4 \\
\pm 1,5 \\
\end{array}$ \\
\hline Сірководень, мг/м³ & 10 & - & $\begin{array}{c}13,9 \\
\pm 1,02 \\
\end{array}$ & $\begin{array}{c}15,4 \\
\pm 0,88^{*} \\
\end{array}$ & $\begin{array}{c}8,8 \\
\pm 0,12 \\
\end{array}$ \\
\hline Вуглекислий газ, \% & 0,25 & - & $\begin{array}{c}0,20 \\
\pm 0,011 \\
\end{array}$ & $\begin{array}{c}0,33 \\
\pm 0,013^{*}\end{array}$ & $\begin{array}{c}0,15 \\
\pm 0,022 \\
\end{array}$ \\
\hline Аміак, мг/м³ & 20,0 & - & $\begin{array}{c}20,6 \\
\pm 1,08\end{array}$ & $\begin{array}{c}27,0 \\
\pm 0,82^{*}\end{array}$ & $\begin{array}{c}16,3 \\
\pm 0,66\end{array}$ \\
\hline Швидкість руху повітря, м/с & $0,5-1,0$ & - & $\begin{array}{c}0,71 \\
\pm 0,08\end{array}$ & $\begin{array}{c}0,41 \\
\pm 0,08\end{array}$ & $\begin{array}{c}1,1 \\
\pm 0,09\end{array}$ \\
\hline Бактеріальна забрудненість,тис. КУО/м³ & $70-120$ & - & $\begin{array}{r}127,6 \\
\pm 5,82\end{array}$ & $\begin{array}{r}164,2 \\
\pm 3,49\end{array}$ & $\begin{array}{l}114,2 \\
\pm 4,7\end{array}$ \\
\hline КСК у збірному молоці,тис/см³ & До 400 & $\begin{array}{r}392,3 \\
\pm 23,1 \\
\end{array}$ & $\begin{array}{r}521,1 \\
\pm 18,9 \\
\end{array}$ & $\begin{array}{c}642,8 \\
\pm 34,2^{*} \\
\end{array}$ & $\begin{array}{r}516,4 \\
\pm 18,9 \\
\end{array}$ \\
\hline Загальне бактеріальне обсіменіння, КУО тис/см³ & до 100 & $\begin{array}{l}98,3 \\
\pm 2,7 \\
\end{array}$ & $\begin{array}{c}221,4 \\
\pm 1,7 \\
\end{array}$ & $\begin{array}{l}356,8 \\
\pm 2,9^{*}\end{array}$ & $\begin{array}{c}321,8 \\
\pm 1,4 \\
\end{array}$ \\
\hline
\end{tabular}

Примітка.-" $p \leq 0,05$ порівняно з нормою.

Приміщення майже не провітрюється, швидкість руху повітря незначна в зв'язку з цим чисте зовні не надходить що і приводить до збільшення бактеріального забруднення. В стійловий період збільшується захворюваність корів на мастит особливо прихованої форми. Показником захворюваності на мастит $€$ вміст соматичних клітин у збірному молоці. Так якщо порівняти вміст СК в літній час та зимовий то їх кількість збільшилась на 249 тис/см³ ${ }^{3}$ Отже за вмістом соматичних клітин молоко не може бути реалізованим ґатунком екстра і навіть вищим. Така сама тенденція спостерігається і у загальному обсіменінні молока. Так загальне обсіменіння молока підвищилось на 258,5 КУО тис/см³ 
Таблиця 2

Мікроклімат корівника та санітарно-гігієнічні показники молока корів за безприв'язного утримання у переобладнаних приміщеннях $(M \pm m, n-5)$

\begin{tabular}{|c|c|c|c|c|c|}
\hline \multirow[b]{2}{*}{ Показники } & \multirow[b]{2}{*}{ Норма } & \multicolumn{4}{|c|}{ Пора року } \\
\hline & & Літо & Осінь & Зима & Весна \\
\hline Температура повітря у приміщенні, ${ }^{\circ} \mathrm{C}$ & $8-12$ & $13,7 \pm 2,1$ & $+8,4 \pm 1,1$ & $+6,2 \pm 1,2$ & $+7,6 \pm 2,1$ \\
\hline Відносна вологість,\% & 70 & $62,8 \pm 0,64$ & $65,2 \pm 0,49$ & $75,7 \pm 0,31$ & $60,4 \pm 1,1$ \\
\hline Сірководень, мг/м³ & 10 & $8,1 \pm 0,83$ & $9,9 \pm 0,20$ & $11,6 \pm 0,31$ & $7,3 \pm 0,11$ \\
\hline Вуглекислий газ, \% & 0,25 & $0,15 \pm 0,01$ & $0,17 \pm 0,08$ & $0,27 \pm 0,04$ & $0,11 \pm 0,03$ \\
\hline Аміак, мг/M³ & 20,0 & $0,10 \pm 0,09$ & $12,4 \pm 1,1$ & $22,0 \pm 0,71$ & $11,3 \pm 0,60$ \\
\hline Швидкість руху повітря, м/с & $0,5-1,0$ & $1,1 \pm 0,09$ & $0,8 \pm 0,09$ & $0,8 \pm 0,07$ & $1,1 \pm 0,04$ \\
\hline Бактеріальна забрудненість,тис. КУО/М³ & $70-120$ & $68,7 \pm 2,11$ & $71,8 \pm 2,80$ & $131,3 \pm 2,49$ & $118,2 \pm 3,7$ \\
\hline КСК у збірному молоці,тис/см³ & До 400 & $312,3 \pm 11,1$ & $371,1 \pm 14,7$ & $453,8 \pm 28,8^{*}$ & $411,3 \pm 14,9$ \\
\hline Загальне бактеріальне обсіменіння молока, КУО тис/см³ & до 100 & $78,4 \pm 1,7$ & $85,6 \pm 1,4$ & $307,8^{*} \pm 12,0$ & $204,8 \pm 1,4$ \\
\hline
\end{tabular}

Примітка.-" $p \leq 0,001$ порівняно до літнього періоду

Наші дослідження показують, що мікроклімат приміщенні за безприв'язному способу утримання табл. 2 навіть у переобладнаних корівниках близький до вимог виробництва молока ґатунку екстра. Що правда в холодний період року нами було зафіксовано тенденцію до підвищення концентрації $\mathrm{CO}_{2}$ сірководню та аміаку ( $\mathrm{p}$-невірогідне). Разом з тим необхідно відмітити що в зимовий період року суттєво збільшується вміст соматичних клітин та бактеріальне обсіменіння молока. Так кількість соматичних клітин порівняно до літнього періоду збільшилась на 141,5 тис/ $\mathrm{cm}^{3}$, а загальне бактеріальне обсіменіння підвищилось на 229,4 тис $\mathrm{KYO} / \mathrm{cm}^{3}(p \leq 0,001)$. Отже аналізуючи результати дослідження мікроклімату приміщення та якості і безпечності молока можна констатувати що в усі періоди року крім зимового мікроклімат відповідає вимогам для тримання тварин та отримання якісного та безпечного молока. Санітарногігієнічні показники якості та безпечності молока в усі періоди року крім зимового відповідають вимогам ДСТУ 2662:2018 Таке молоко можна реалізовувати згідно вищого ґатунку і навіть екстра за показниками кількості соматичних клітин та загального бактеріального обсіменіння. Разом з тим ми провели санітарно-гігієнічну оцінку і визначили якість та безпечність молока корів чорно-строкатої породи за умов безприв'язного утримання у ТОВ АФ «Надія» Борзнянського району Чернігівської області. Дослідження проводилось у заново побудованому приміщенні на 2000 голів корів де виробництво молока проходить за новітньою промисловою технологією. За попередній 2019 рік продуктивність тварин склала 9834 кг. У дослідному приміщенні знаходяться лише дійні корови. Корівник через галерею з'єднується з накопичувачем та молочним блоком. Годівля тварин однотипною кормовою сумішшю круглий рік. Кормову суміш роздають трактори-кормозмішувачі. Гній видаляють за допомогою дельта-скребка а потім до гноєсховища де його сушать і повторно використовують як підстилку. Доїння проводиться протягом доби приблизно через 8 годин. Доїльна установка типу «Паралель» фірми ДеЛаваль. Після кожного доїння використовують консервацію дійок. Загальний об'єм приміщення в межах 70588 м³. Внутрішня висота приміщення в межах 8,5 м що суттєво впливає на загазованість. На одну корову припадає близько 35,3 м ${ }^{3}$. Газообмін проходить через надбудови які розташовані по всій довжині конька. Дослідження проводилось за сезонами року. Результати дослідження наведені у нижче розташованій таблиці 3.

Результати наших досліджень показують що при цілодобовому круглорічному утриманні корів у приміщенні показники мікроклімату в різні пори року відрізняються. Та якщо розглянути температуру у приміщенні то вона варіює від $+21^{\circ} \mathrm{C}$ влітку до $-6,3^{\circ} \mathrm{C}$ взимку (а в деякі періоди навіть до $-10^{\circ} \mathrm{C}$ ) що не відповідає норм (ВНТП-АПК-01.05). Тобто за температурою у приміщенні лише такі періоди як весна та осінь відповідають вимогам щодо утримання дійних корів. Необхідно відмітити що в холодний період року для напування вода підігрівається до $25-30^{\circ} \mathrm{C}$. У жаркий період року використовують установку “Спрей”, яка зволожує повітря що в свою чергу підвищує вологість приміщення. Разом 3 тим такі показники мікроклімату як сірководень, вуглекислий газ та аміак знаходяться нижче допустимих меж.

Таблиця 3

\section{Мікроклімат корівника та санітарно-гігієнічні показники молока корів} отриманого за новітніх технологій $(\mathrm{M} \pm \mathrm{m}, \mathrm{n}-5)$

\begin{tabular}{|c|c|c|c|c|c|}
\hline \multirow{2}{*}{ Показники } & \multirow{2}{*}{ Норма } & \multicolumn{4}{|c|}{ Пора року } \\
\hline & & Літо & Осінь & Зима & Весна \\
\hline Температура повітря у приміщенні, ${ }^{0} \mathrm{C}$ & $8-12$ & $21,6 \pm 3,2$ & $+10,3 \pm 2,1$ & $-6,3 \pm 2,1$ & $+11,9 \pm 2,2$ \\
\hline Відносна вологість, $\%$ & 70 & $83,4 \pm 0,34$ & $63,2 \pm 0,51$ & $73,7 \pm 0,31$ & $60,4 \pm 1,1$ \\
\hline Сірководень, мг/м³ & 10 & $6,1 \pm 0,73$ & $7,4 \pm 0,16$ & $8,0 \pm 0,11$ & $7,3 \pm 0,12$ \\
\hline Вуглекислий газ, \% & 0,25 & $0,12 \pm 0,02$ & $0,12 \pm 0,09$ & $0,14 \pm 0,03$ & $0,11 \pm 0,04$ \\
\hline Аміак, мг/M³ & 20,0 & $0,9 \pm 0,08$ & $12,4 \pm 1,1$ & $15,0 \pm 0,53$ & $13,4 \pm 0,32$ \\
\hline Швидкість руху повітря, м/с & $0,5-1,0$ & $1,1 \pm 0,07$ & $0,8 \pm 0,09$ & $0,6 \pm 0,04$ & $1,1 \pm 0,03$ \\
\hline Бактеріальна забрудненість,тис. КУО/см³ & $70-120$ & $58,4 \pm 1,11$ & $64,7 \pm 1,34$ & $84,3 \pm 1,09$ & $72,3 \pm 1,7$ \\
\hline КСК у збірному молоці,тис/см ${ }^{3}$ & До 400 & $211,2 \pm 10,2^{*}$ & $214,8 \pm 11,3^{*}$ & $221,1 \pm 14,8^{*}$ & $213,7 \pm 14,9^{*}$ \\
\hline Загальне бактеріальне обсіменіння молока, КУО тис/см³ & до 100 & $54,9 \pm 1,6$ & $65,4^{*} \pm 1,3$ & $70,8^{*} \pm 1,9$ & $63,8^{*} \pm 1,5$ \\
\hline Захворюваність на мастит, $\%$ & - & 5,6 & 5,5 & 6,4 & 6,2 \\
\hline
\end{tabular}

Примітка.- ${ }^{*} \leq 0,001$ порівняно до літнього періоду

На наш погляд це пов'язано з тим що у перехідні пе- | ріоди року підвищений рух повітря у приміщенні. Разом 3 
тим ми провели дослідження загального бактеріального обсіменіння молока, вмісту соматичних клітин та відсотку захворювання на мастит. Так з а нашими дослідженнями загальне бактеріальне обсіменіння молока в усі пори року не перевищувало межу КУО 100 тис/см ${ }^{3}$ і знаходилось у межах

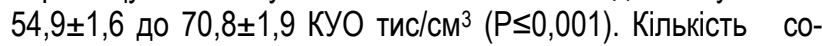
матичних клітин була нижче від допустимої норми на 178,9 тис/см³. Отже санітарно-гігієнічні показники молока відповідають ґатунку екстра. Разом з тим за проведеним нами дослідженням захворювання корів на мастит відсоток хворих не перевищував 6,4\%. Наші дослідження підтверджуються тим що ТОВ АФ «Надія» все молоко на переробні підприємства здає ґатунком екстра. Отже якість та безпечність молока напряму залежить від технології його виробництва.

\section{Висновки.}

1. Нашими дослідженнями встановлено що якість та безпечність молока напряму залежить від технології його виробництва. За використання новітньої технології виробництва молока кількість соматичних клітин та загальне обсіме-

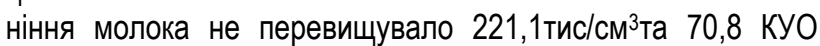
тис/см³. Що відповідає ґатунку екстра.

2. Захворювання корів на мастит при виробництві молока за новітньою технологією у ТОВ АФ «Надія» не перевищує 6,4 відсотка.

3. За використання новітньої технології виробництва молока в зимовий період часу температура в приміщення може опускатися до $-10^{\circ} \mathrm{C}$, але це не приводить до збільшеності захворювання на мастит та органи дихання.

\section{References}

1. Andrievskyi, V.Y., Kostenko, O.I., Ostapiuk, M.P., Kasianchuk, V.V., Skliar, O.I., 2013. Quality management systems. Milk. Calculation of somatic cells. Part 1. Microscope method (control method) (ISO 13366-1: 2008 IDF 148-1:2008): DSTU ISO 13366-1: 2008. Kyiv: State Consumer Standard of Ukraine, 12.

2. Arulraj, P., Asarudheen, I., Jasmin, T., Mohammed, Sarfas, Sahnas, N.K., Vedha, Satheesh, Venkatanarayanan, R., 2015. Dairy bacteriology and microbial analysis of milk using syringe filter. European Journal of Biomedical and Pharmaceutical Sciences 2, 380-388

3. Busato, A., Trachsel, P., Schallibaum, M., Blum, J.W., 2000. Udder health and risk factors for subclinical mastitis in organic dairy farms in Switzerland. Preventive Veterinary Medicine 44, 205-220. [CrossRef]. DOI: 10.1016/s0167-5877(00)00104-5

4. Dorofeev, O. V. and Buncev, V. E. (2015), "The role of staff in ensuring competitive advantages of the agrarian enterprose", Antropologihni aspekty upravlinnia suhasnym pidpryemstvom : vseukrainska naukovo-praktyhna Internet-konferenzia [Anthropological aspects of management of a modern enterprise : Ukrainian scientific and practical Internet-conference], PDAA, Poltava, Ukraine.

5. Dufour, S., Frechette, A., Barkema, H.W., Mussell, A., Scholl, D.T., 2011. Invited review: effect of udder health management practices on herd somatic cell count. Journal of Dairy Sciences 94, 563-579. [CrossRef]. DOI: 10.3168/jds.2010-3715

6. Hulich, M.P. (2011), "Balanced diet and healthy lifestyle - key factors maintaining the health of the population", Problemy starenyia y dolholetyia, vol. 2, pp. 128-132

7. Hussain, R., Javed, M.T., Khan, A., 2012. Changes in some biochemical parameters and somatic cell counts in the milk of buffalo and cattle suffering from mastitis. Pakistan Veterinary Journal 32, 418-421.

8. Joshi, S., Gokhale, S., 2006. Status of mastitis as an emerging disease in improved and periurban dairy farms in India. Annals of the New York Academy of Sciences 1081, 74-83. [CrossRef]. DOI: 10.1196/annals.1373.007

9. Kernasyuk, Y. (2015), "Robotized cow milking: recoupment of investments", Online, availableat : http://www.agrobisiness.com.ua/suchasne-tvarynnytstvo/3978.html (Accessed 15 Oct 2017).

10. Kostenko, V. (2013), "Milking of cows, evaluation and selection of firstlings", [Online], available at: http://www.agrobisiness.com.ua/suchasne-tvarynnytstvo/1530.html (Accessed 15 Oct 2017)

11. Kostenko, V. (2015), "Economy of milk production", [Online], available at : http://www.agro-bisiness.com.ua/suchasnetvarynnytstvo/3171.html (Accessed 15 Oct 2017).

12. Kyryliuk, I. (2016), "Current approaches to guarantee the quality and safety of animal products in the EU", Efektyvna ekonomika, vol. 12, available at: http:// http://www.economy.nayka.com.ua/?op=1\&z=5330 (Accessed 03 Sep 2017)

13. Lelieveld, H.L.M., Holah, J., Gabric, D., 2016. Handbook of Hygiene Control in the Food Industry, (Woodhead Publishing Series in Food Science, Technology and Nutrition), 2nd Edition, Woodhead Publishing.

14. Livestock Production Technology (2005), "Milking of cows", [Online], available at : http://buklib.net/books/34166/ (Accessed 15 Oct 2017).

15. Lucenko, M. and Zvoleyko, D. (2012), "Research of the process of milking cows in the specialized milking parlours", Technika i technologyi v APK, , vol. 9(36), pp. 31-34.

16. Lucenko, M. and Zvoleyko, D. (2013), "Efficiency of using robotized milking systems", Technika $i$ technologyi $v$ APK, , vol. 5(44), pp. 13-15

17. Ma, Y., Ryan, C., Barbano, D.M., Galton, D.M., Rudan, M.A., Boor, K.J., 2000. Effects of somatic cell count on quality and shelf-life of pasteurized fluid milk. Journal of Dairy Sciences 83, 264-274. [CrossRef]. DOI: https://doi.org/10.3168/ids.S0022$\underline{0302(00) 74873-9}$

18. Shkromada, O., Palii, A., Palii, A., Skliar, O., Dudchenko, Y., \& Necherya, T. (2019). Improvement of milk quality for micro-climate formation on cattle farms. Bulletin of Sumy National Agrarian University. The Series: Veterinary Medicine, (4 (47), $43-$ 49. DOI: https://doi.org/10.32845/bsnau.vet.2019.4.7

19. Mankiewicz, R., 2004. The Story of Mathematics. Princeton, NJ: Princeton University Press.

20. Marshall, R.T., 1992. Standard Methods for the Examination of Dairy Products, 16th ed. American Public Health 
Association, Washington, DC.

21. Murphy, S.C., Boor, K.J., 2000. Trouble-shooting sources and causes of high bacteria counts in raw milk. Dairy, Food and Environmental Sanitation 8, 606-611.

22. Otenko, V. I. (2014), "Competitive advantages of business activities", Biznes inform, , vol. 4 (435), pp. 290-295.

23. Smolar, V.I. (2013), "Formula nutrition", Problemy kharchuvannia, vol. 2, pp. 5-9.

24. Zamoyski, K. Zamoyski, C. Wilczynski, J. and Chorna, O. (2014), "Nutrition students", Naukovi zapysky: Pedahohichni nauky, vol. 132, pp. 319-323.

I.W. Gerun, postgraduate student, Sumy National Agrarian University (Sumy, Ukraine)

O.I. Sklyar, Sumy National Agrarian University (Sumy, Ukraine)

O.V. Musiienko, Sumy National Agrarian University (Sumy, Ukraine)

The influence of milk production technology on its quality and safety

In the article, the authors have studied a significant amount of literature related to milk production technology. Under modern conditions of milk production there is a necessary need to study a set of preventive measures. Which would allow to make full use of genetic potential of animals and at the same time to keep health and to receive qualitative and safe production from them. At present, there is a large amount of technological news, which is aimed at obtaining the highest productivity at the lowest cost. The use of industrial technologies often does not take into account the natural needs of animals, which are scientifically sound to meet a certain physiological group. The authors conducted a parallel study of three milk production technologies with different systems of keeping cows. The article presents data on the sanitary and hygienic condition of the farm in milk production using traditional and the latest technology. In this work, studies of the microclimate in the premises for cows and its impact on the quality and safety of milk were conducted. Our research has shown that the quality and safety of milk directly depends on the technology of its production. With the use of the latest milk production technology, the number of somatic cells and total milk contamination did not exceed 221.1 thousand $/ \mathrm{cm}^{3}$ and $70.8 \mathrm{CFU}$ thousand $/ \mathrm{cm}^{3}$, respectively. However, it was found that with the use of the latest technology of milk production in the winter time, the room temperature can drop to $-10^{\circ} \mathrm{C}$, but this does not lead to an increase in mastitis and respiratory diseases. The incidence of mastitis in cows does not exceed 6.4 percent, which is one of the best indicators.

Key words: microclimate, milk, hydrogen sulfide, ammonia, relative humidity, total bacterial contamination, air velocity, carbon dioxide, cows, mastitis.

Дата надходження до редакції: 29.11.2020 р. 